\title{
Influence of the Hepatoprotector on Production Performance in Fattening Pigs - Research Results and Perspectives
}

Teodora VASILJEVIĆ' ${ }^{1}$ Ištvan ŠOMOĐI ${ }^{1}$, Nenad STOJANAC ${ }^{2}$, Radoslav DOŠEN ${ }^{3}$, Dušan LALOŠEVIĆ ${ }^{4}$, Zdravko TOMIĆ ${ }^{5}$ Žarko AVRAMOV ${ }^{1}$

${ }^{1}$ Patent Co, Belgrade, Serbia, Ištvan

${ }^{2}$ Agricultural Faculty, Universtiy of Novi Sad, Novi Sad, Serbia,

${ }^{3}$ Scientific Veterinary Institute "Novi Sad",Novi Sad, Serbia

${ }^{4}$ Paster Institute,Novi Sad, Novi Sad, Serbia,

${ }^{5}$ Neoplanta Pig Farm, Novi Sad, Serbia,

*Corresponding author e-mail: teodora.vasiljević@patent-co.com

Bulletin UASVM Veterinary Medicine 71(2) / 2014,

Print ISSN 1843-5270; Electronic ISSN 1843-5378

DOI:10.15835/buasvmcn-vm: 10740

\begin{abstract}
Commercial, industrial pig production requires from manufacturer, to produce a large number of fattening pigs per sow per year, with most rational business, smaller losses in all production stages, greater growth and achievement the desired final weight in the shortest possible time. To make production economically viable in the conditions present on most domestic commercial pig farms with regard to the accommodation and environmental conditions, the present technology and health status is important to allow such animal nutrition that will satisfy the nutritional and health requirements and allow the animals adequately respond to the physiological burdensome conditions of intensive production in the body and exert maximum existing genetic potential in farm conditions. In our study conducted on a large commercial farm, inclusion hepatoprotective preparation based on flavonoids from plant extracts and phosphoryl choline chloride as an feed additives several significant improvements in production are realized: reducing mortality, increased weight gain in fattening the higher meat yield in a shorter time and to improve health status of fattening pigs confirmed through lower losses (deaths and forced to slaughter. In the study followed the production parameters, metabolic profiles of the test animals, the clinical observation of internal organs on the slaughter and histopathological examination of a sample of 90 fattening pigs. Based on these results we consider that the introduction of hepatoprotective preparation as a supplement in animal feed is fully justified and that further research in this direction can bring great benefits to domestic producers of pigs.
\end{abstract}

Keywords: flavonoids, health status, production indicators

\section{INTRODUCTION}

Free radicals and oxidative stress are terms that increasingly preoccupied both human and veterinary medicine of the 21st century, and are so closely connected in antioxidants. According to the definition of antioxidants (Britton, 1995), these are molecules that remove the free radicals created them is less harmful to the molecules or terminate the chain reaction caused by free radicals. The oxidants stress leads to excessive production of free radicals, which cause oxidative damage, cell death and tissue which consequently leads to a distortion of the general health status of the organism. The level of oxidative stress is the basis of a number of diseases and disorders in human and veterinary medicine and as a result, the use of antioxidants becomes more important because of its effect on the free radicals. When it comes to veterinary medicine, as well as its role in an intensive, farm exploitation of animals, preventive and curative measures which it has as a means of preserving the health status of animals in conditions of intensive exploitation is relatively limited to the control of infectious 
agents. The resolution of metabolic disorders such factors can greatly affect the level of production parameters in animal production as well as its very economical and cost-effectiveness of paramount importance to a balanced diet for each species and animals categories in a way that through proper formulation and technology of food animals allow proper physiological processes in the body and thus maximum productivity in terms of genetic possibilities and present conditions in which they live and produce.

Hepatoprotectives - the importance and possibility of application in pig production

It is known that the liver is involved in the processes of the metabolism of carbohydrates, fats, proteins, as well as water and the salts, pigments, vitamins, hormones. One of the most important liver function is detoxification and is related to the removal of toxic substances from the body. Often hepatocyte damage caused by various harmful substances is the result of just its central role in metabolism. Situated between gastrointestinal tract and peripheral organs, the liver is permanently exposed to the influence of various substances whose metabolism can result in toxic intermediate compounds, which can cause or increase the already present liver damage. Many toxins that enter the body via the gastrointestinal tract requires a conversion from the insoluble to the soluble metabolites, so they can be excreted via the urine or bile. Drugs, a toxic product present in the animal feed or created in the body by decarboxylation of the amino acids from protein, under the action of bacteria in the intestines (histamine, tyramine, putrescine, cadaverine, spermine), some supplements (additives, emulsifiers, coloring agents, etc.) and a host of other harmful substances liver animals need to detoxify and remove from the body. When the liver is too burdened and unable to cope with such a quantity of hazardous substances, the cells of the liver are damaged, and they cannot perform their function. Are replaced by connective cells causing liver is no longer able to perform its primary function. Hepatoprotectives are intended to protect the liver from damage and normalize its operations after infectious, toxic, viral and other harmful effects. These are a variety of biologically active substances that protect the membrane of hepatocytes, normalize and improve their interaction and function. Flavonoids are substances synthesized only in plants, animals and people are not able to produce them yourself. Scientifically proven effects of flavonoids in humans have protective effect on the liver, inhibition of fat oxidation, antiviral and antibacterial properties, regeneration of the skin and mucous membranes, and antitumor activity. The basic pharmacological activity of flavonoids is associated with their effect on the wall of the blood vessels of the peripheral circulation. Reduce permeability and fragility, and increase the elasticity and tone of the main wall of the capillary. Effect of flavonoids on the capillary may be explained by their ability, as a proton donor, to prevent the reduction of dehydroascorbic acid and thus protect vitamin C. Another explanation is that these natural polyphenols inhibit enzymes (hyaluronidase, elastase and catechol-0-methyltransferase) and slows down the degradation of elastin. Flavonoids are found application in the treatment of different diseases that are caused by the disorder and hepatic blood and lymph vessels of the peripheral circulation. To livers could fulfills its main role and detoxify a large amount of toxic substances, a large amount of energy that is enough glycogen in the liver. In cases where there is not enough glycogen available when intensive detoxification processes in the liver to accumulate fat which liver cells are trying to provide enough glucose. In extreme conditions, the content of fat in the liver can be very large with nastajenjem fatty degeneration of hepatocytes and liver function disorder itself. Phosphoryl choline chloride reduces the amount of fat in the liver helps process the glucose production, and thereby facilitates the process of elimination of toxic substances as an additional energy source. Phosphoryl choline chloride represents a biologically active substance choline chloride, which occurs physiologically in the liver. Adding external phosphorylcholine chloride, this process is significantly facilitates its direct involvement in the processes of fat metabolism in the liver.

\section{MATERIAL AND METHOD}

On the commercial farm of 1500 sows in Serbia, we conducted a survey on the impact of the hepatoprotective preparation of the health status and production performance of fattening pigs by adding it to the standard mixture in an amount of $2 \mathrm{~kg} / \mathrm{t}$ of food. The farm is loaded with the usual medical pathology of domestic 
pig farms. Testing was performed 19/11/2013. 03/07/2014. 90 finishing pigs were included in the examination, from entering into the fattening stable up delivery. The aim of the experiment was to examine the effect of the hepatoprotective preparation PRO-FORTE based on plant extracts and phosphorylcholine chloride on: General health of fatteners, increase the final mass slaughter fattening pigs, increase growth and reduce mortality. The experiment included 45 pigs in the experimental group and 45 in the control group. Experimental group was fed with standard mixture used on the farm at this stage, with the addition of $2 \mathrm{~kg} / \mathrm{t}$ mixture PRO-FORTE made by Patent Co. A control group was fed the standard mixture used at the farm use at this stage on farm.

The parameters monitored in the experiment were: 1 . The number of pigs at the beginning and end of the experiment; 2 . Total weight of pigs at the beginning of the experiment; 3. Average weight piglets; 4 . The number of fattening pigs at delivery (experiment and control); 5. Total weight at delivery; 6 Percent death; 7 Percent emergency slaughter; 8. Total growth 9. AverageADG-group. During the experiment, we followed by the metabolic profiles of piglets on the basis of biochemical parameters in the blood of piglets on the same sample of 40 pigs (20 experimental +20 in the control group) at the beginning of the experiment, 60 days and 120 days. The parameters which were monitored are: total protein, albumin, total bilirubin, transaminases, glucose, $\mathrm{Ca}, \mathrm{P}$, creatinine, uric acid. At the end of the experiment was carried out inspection bodies porkers experimental and control groups on the slaughter line. Collected data on body weight and daily gain of fattening pigs in the experiment were statistically analyzed, appropriate statistical

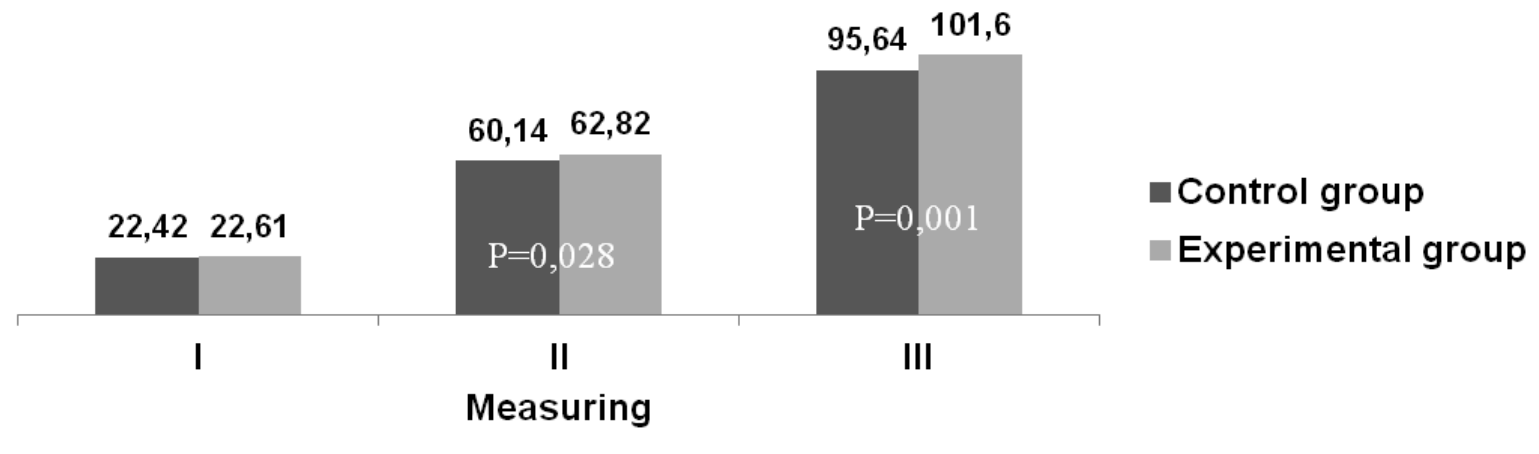

Fig. 1. Results of measurements of body mass of piglets, the control and experimental groups.



Fig. 2. The growth of the piglets during the experiment, the control and experimental groups. 
methods. The obtained results were analyzed using the demo version of the statistical program PASW Statistics 18 https://www.spss.com/Registration/ premium/consol056.cfm?Demo_id=37).

\section{RESULTS AND DISCUSSION}

Tab. 1. Biochemical parameters of blood at the first sampling.

\begin{tabular}{|c|c|c|}
\hline Indicator & $\begin{array}{c}\text { Experimental } \\
\text { group }\end{array}$ & $\begin{array}{c}\text { Control } \\
\text { group }\end{array}$ \\
\hline Albumin $(2.3-4.0 \mathrm{~g} / \mathrm{dl})$ & 2,6 & 2,7 \\
\hline $\begin{array}{c}\text { Creatinine } \\
(39-132 \mu \mathrm{mol} / \mathrm{l})\end{array}$ & 108,0 & 97,8 \\
\hline Tot.prot (Do 8,6 g/dl) & 5,4 & 5,8 \\
\hline Glu $(3,9-6,3 \mathrm{Mmol} / \mathrm{l})$ & 5,4 & 6,1 \\
\hline Tot.bil $(0-8,5 \mu \mathrm{mol} / \mathrm{l})$ & 11,6 & 6,5 \\
\hline $\operatorname{ALP}(0-176 \mathrm{IU} / \mathrm{l})$ & 141,5 & 158,5 \\
\hline ALT $(21-46,5 \mathrm{IU} / \mathrm{l})$ & 72,4 & 67,7 \\
\hline AST (15-53 IU/l) & 102,0 & 80,5 \\
\hline $\mathrm{Ca}(2,4-3,0 \mathrm{Mmol} / \mathrm{l})$ & 2,0 & 2,5 \\
\hline $\mathrm{P}(1,8-3 \mathrm{Mmol} / \mathrm{l})$ & 3,0 & 3,0 \\
\hline $\begin{array}{c}\text { Uric acid }(0-102,3 \\
\mu \mathrm{mol} / \mathrm{l})\end{array}$ & 29,6 & 28,6 \\
\hline
\end{tabular}

Tab. 2. Biochemical parameters of blood at the second sampling.

\begin{tabular}{|c|c|c|}
\hline Indicator & $\begin{array}{c}\text { Experimental } \\
\text { group }\end{array}$ & $\begin{array}{c}\text { Contro } \\
\text { group }\end{array}$ \\
\hline Albumin $(2.3-4.0 \mathrm{~g} / \mathrm{dl})$ & 2,9 & 3,0 \\
\hline $\begin{array}{c}\text { Creatinine } \\
(39-132 \mu \mathrm{mol} / \mathrm{l})\end{array}$ & 139,2 & 128,6 \\
\hline Tot..prot (Do 8,6 g/dl) & 5,5 & 5,7 \\
\hline Glu $(3,9-6,3 \mathrm{Mmol} / \mathrm{l})$ & 4,6 & 4,7 \\
\hline Tot.bil $(0-8,5 \mu \mathrm{mol} / \mathrm{l})$ & 10,5 & 6,9 \\
\hline $\operatorname{ALP}(0-176 \mathrm{IU} / \mathrm{l})$ & 109,1 & 105,7 \\
\hline ALT (21-46,5 IU/l) & 53,0 & 56,1 \\
\hline AST (15-53 IU/l) & 66,8 & 50,3 \\
\hline $\mathrm{Ca}(2,4-3,0 \mathrm{Mmol} / \mathrm{l})$ & 2,6 & 2,4 \\
\hline $\mathrm{P}(1,8-3 \mathrm{Mmol} / \mathrm{l})$ & 2,9 & 2,9 \\
\hline $\begin{array}{c}\text { Uric acid }(0-102,3 \\
\mu \mathrm{mol} / \mathrm{l})\end{array}$ & 38,5 & 28,2 \\
\hline
\end{tabular}

Tab. 3. Biochemical parameters of blood at the third sampling

\begin{tabular}{|c|c|c|}
\hline Indicator & $\begin{array}{c}\text { Experimental } \\
\text { group }\end{array}$ & $\begin{array}{l}\text { Control } \\
\text { group }\end{array}$ \\
\hline Albumin $(2.3-4.0 \mathrm{~g} / \mathrm{dl})$ & 3,2 & 3,0 \\
\hline $\begin{array}{c}\text { Creatinine } \\
(39-132 \mu \mathrm{mol} / \mathrm{l})\end{array}$ & 146,4 & 135,7 \\
\hline Tot.prot (Do 8,6 g/dl) & 6,4 & 6,4 \\
\hline Glu (3,9-6,3Mmol/l) & 3,9 & 3,3 \\
\hline Tot..bil $(0-8,5 \mu \mathrm{mol} / \mathrm{l})$ & 5,1 & 4,5 \\
\hline $\operatorname{ALP}(0-176 \mathrm{IU} / \mathrm{l})$ & 117,5 & 73,2 \\
\hline ALT (21-46,5 IU/l) & 63,8 & 56,6 \\
\hline AST (15-53 IU/l) & 47,3 & 44,8 \\
\hline Ca $(2,4-3,0 \mathrm{Mmol} / \mathrm{l})$ & 2,2 & 2,4 \\
\hline $\mathrm{P}(1,8-3 \mathrm{Mmol} / \mathrm{l})$ & 3,0 & 3,0 \\
\hline $\begin{array}{c}\text { Uric acid }(0-102,3 \\
\mu \mathrm{mol} / \mathrm{l})\end{array}$ & 19,4 & 25,7 \\
\hline
\end{tabular}

Results of measurements of body mass of piglets, the control and experimental groups are shown in Fig. 1.

Results of measurements of body mass of piglets, the control and experimental groups are shown in Fig. 2

Biochemical parameters in pig blood samples are shown in tables 1,2 and 3

Loos of piglets during trial (death and the slaughter) are showed in Table 4

List of slaughterhouse reviews lungs of slaughtered pigs is showed in Table 5

Patohistological examination internal organs. Pathohistological findings of the trial group are presented in Figure 3a.

Body weight: The average body weight of finishing pigs at the beginning of the experiment was $22,61 \mathrm{~kg} 22,41 \mathrm{~kg}$ the experimental and the control group (Chart 1). Body weight of fattening

Tab. 4. Loss of piglets during the course of the experiment

\begin{tabular}{|c|c|c|c|c|c|}
\hline & $\begin{array}{c}\text { Death } \\
\text { piglets, } \\
\text { no }\end{array}$ & $\mathbf{\%}$ & $\begin{array}{c}\text { Slaughter } \\
\text { piglets, } \\
\text { no }\end{array}$ & \% & $\begin{array}{c}\text { Total } \\
\text { losses } \\
\text { \% }\end{array}$ \\
\hline $\begin{array}{c}\text { Control } \\
\text { group }\end{array}$ & 1 & 2,22 & 2 & 4,54 & 6,66 \\
\hline $\begin{array}{c}\text { Experimental } \\
\text { group }\end{array}$ & 1 & 2,17 & 0 & 0 & 2,17 \\
\hline
\end{tabular}


Tab. 5. List of slaughterhouse reviews lungs of slaughtered pigs:

\begin{tabular}{|c|c|c|}
\hline Type of change & $\begin{array}{l}\text { Experimental } \\
\text { group }\end{array}$ & Control group \\
\hline \multicolumn{3}{|l|}{$\begin{array}{l}\text { Pneumonia catarrhalis, mykoplasma } \\
\text { Apical lobes only }\end{array}$} \\
\hline Apical and cardial lobes & 3 & 4 \\
\hline Apical, cardial and diaphragmatic lobes & 5 & 9 \\
\hline Pneumonia catarrhalis with complications & - & - \\
\hline Pneumonia catarrhalis disseminata (lobular.) & - & - \\
\hline Pneumonia fibrinosa & - & - \\
\hline Pneumonia fibrinosa partim necrotica & - & - \\
\hline Pneumonia apostematosa disseminata & - & - \\
\hline Pleuropneumonia acuta/ subacuta & - & 3 \\
\hline Pleuropneumonia chronica & - & - \\
\hline Chron. Pleuritis localised & - & 3 \\
\hline Chron. pleuritis, generalisata & - & 1 \\
\hline Pericarditis serosa & - & - \\
\hline TOTAL: & 8 & 20 \\
\hline Milk stains & 1 & 1 \\
\hline
\end{tabular}
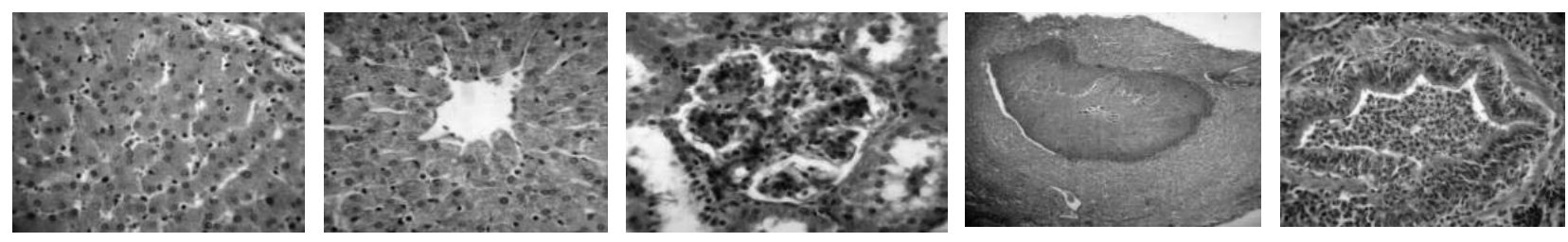

Fig. 3a. Pathohistological findings of the trial group.

1) Liver - preserved hepatocytes on the outskirts of the cross-section,

2) Liver - centrilobular vein of regular appearance, surrounded by hepatocytes of granular cytoplasm,

3) Kidney - preserved condition of glomerulus,

4) Lung actinomycosis,

5) Bronchiolitis purlenta acuta
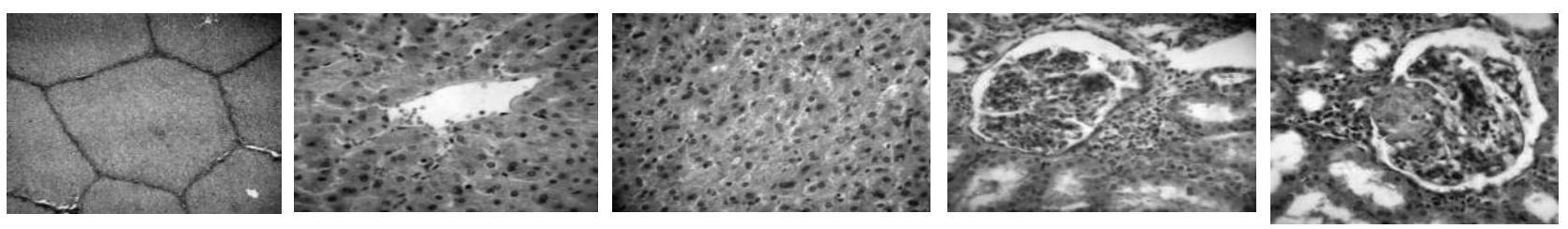

Fig. 3b. Pathohistological findings of the control group.

1) Liver - general look, well preserved lobular structure,

2) Liver, region of centrilobular vein appears regular, surrounding sinusoids very narrowed, bright hepatocytes, granular cytoplasm,

3) Liver, hepatocytes mostly enlarged, bright granular cytoplasm, sinusoids compressed,

4) Kidney with focal lymphocytic infiltrate between the tubules,

5) Kidney, a proliferative change in one of the glomerulus. 
pigs was the control measurement (60 days) $62,8125 \mathrm{~kg} 60,8152 \mathrm{~kg}$ in the experimental and the control group which was statistically significantly higher $(p=0.028)$. At the final measurement of body mass finishing pigs in the experimental group was $101,6 \mathrm{~kg}$ a $95,642 \mathrm{~kg}$ in the control group, which was statistically significantly higher $(\mathrm{p}=0.001)$.

Daily gain of piglets: Growth of the first and second measurements was the experimental group $0.628 \mathrm{~kg}$ / day, which was statistically significantly higher ( $p=0.007)$ of $0.589 \mathrm{~kg} /$ day, what was the increase in the control group. Gain from the second to the third measurement was in the experimental group 0,878 kg / day, which was significantly higher $(p=0.011)$ of $0.807 \mathrm{~kg} /$ day, what was the increase in the control group. The total increase in the experiment in the experimental group was $0.731 \mathrm{~kg} /$ day, which was statistically significantly higher $(\mathrm{p}=0.000)$ compared to the control group, in which the gain was $0.678 \mathrm{~kg} /$ day (Chart 2).

Losses of piglets: During the trial total losses of piglets (death and forced to slaughter) in the experimental group was $6.66 \%$ compared to the control which were $2.17 \%$ (Table 4). Biochemical indicators: 1 . creatinine concentration in the experimental group showed a tendency to increase, which can be interpreted in proportion to the increase in muscle mass and metabolic activities designed. Creatinine can also be increased in the experimental group due to lack of food (degraded their muscles that make up proteins), poor blood supply to the kidneys due to low blood pressure, haemoconcentration, increased physical activity. 2 ALP in the experimental group increased in the second and third measurement, because there is increased activity of bone metabolism. Due to the increased growth of the experimental group, Ca does not have enough available to support increased growth and weight gain of the experimental group. In contrast to the control group in which the $\mathrm{Ca}$ is the physiological fairness in all three measurements. Due to the mobilization of Ca from depots in the bones, ALP is therefore increased. Do not view this group was to increase the provision of $\mathrm{Ca}$ in the diet and thus support growth even better. Uric acid in the experimental group during the second measurement showed an increase in concentration. The secondary may occur in the degradation of proteins due to their own lack of food. The fact that the experimental group had greater weight gain compared to control. If we take into account that received the same amount of food in the experimental group was markedly following:

- Increased creatinine as a result of the degradation of its own protein ;

- Increased uric acid secondary to protein catabolism;

- Increased ALP primarily due to insufficient intake of calcium and mobilization of Ca from the bones for growth.

Transaminases, despite the expected showed no significant difference between the groups, which was confirmed by histopathological findings. Positive impact of hepatoprotective additive was confirmed on the level of metabolism and increased weight gain in the experimental group. Slaughter examination of internal organs slaughter examination of organs of slaughtered fattening pigs were observed striking macroscopic changes in the livers and kidneys in the control than in the experimental group. The lungs of slaughtered fattening pigs distinct histological changes were observed in 20 fattening pigs (47.61\%) in the control and 8 finishing pigs $(18 \%)$ in the experimental group.

\section{CONCLUSION}

Based on the above it can be concluded that the application of the preparation Proforte as an supplement in the diet of fattening pigs achieved significant improvement in production parameters investigated pig, achieved a positive effect on health, reduced losses to the favorable financial effect

\section{REFERENCES}

1. https://www.spss.com/Registration/premium/ consol056.cfm?Demo_id=37 (2010): PASW Statistics 18. Demo versioon of software.

2. Chaudhary GD at all (2010). Herbs as liver savers - A review, Indian Journal of Natural Products and Resources 1(4):397-408

3. Shashank K, Pandey AK (2013). Chemistry and Biological Activities of Flavonoids: An Overview, The Scientific World Journal, Article ID 162750, 16 p.

4. Laudato M, Capasso R (2013). Useful plants for animal therapy. OA Alternative Medicine Italy, 1(1):1.

5. Kumar SV, Bihani GL (2012). A Review on Hepatoprotective Activity of Medicinal Plants International Journal of Advanced Research in Pharmaceutical\&Biosciences, 2012 
6. Jain N, Ramawat KG (2013). Nutraceuticals and Antioxidants in Prevention of Diseases. Natural Products, 2559-2580. Springer Berlin Heidelberg

7. Rangel J (2009).Hepato phyto-nutraceutical synergistic composition, US Patent 7,625,587

8. Das B, Sarkar SK, Panda S (2011). Comparative efficacy of dietary supplementation of synthetic choline chloride vis-àvis herbal choline in broiler ration. Indian Journal of Poultry Science 46(3): 405-407
9. Stanković MN, Mladenovic DR, Duncic I, Sobajic SS et al. (2014). Time-dependent Changes and Association Between Liver Free Fatty Acids, Serum Lipid Profile and Histological Features in Mice Model of Nonalcoholic Fatty Liver Disease, Archives of Medical Research,45(2):116-124.

10. Ueland PM (2011). Choline and betaine in health and disease, Journal of Inherited Metabolic Disease 34(1): 3-15. 